\title{
Hvordan lages en medisinsk ordbok?
}

\author{
Medisinske ordbøker både beskriver og former det medisinske fag- \\ språket. I små språkområder, som det norske, har ordbøkene stor \\ betydning for utviklingen av en nasjonal medisinsk terminologi. \\ Det er tre hovedoppgaver i arbeidet med en medisinsk ordbok: å finne \\ det rette ordutvalget, å bestemme skrivemåten av enkeltord og å gi en \\ kort og korrekt forklaring på ordenes betydning. \\ Målgrupper og bruksområder for en medisinsk ordbok er vide. \\ Legfolk og helsepersonell under utdanning vil lete etter ordforklaringer, \\ mens mer spesialiserte og erfarne grupper vil ha mest nytte av anbe- \\ falte skrivemåter.
}

\section{"The limits of my language are the limits of my mind. All I know is what I have words for»}

Ludwig Wittgenstein (1889-1951) (1)

Ordsamlinger har sannsynligvis eksistert like lenge som skriftspråkene, og ordbøker ble særlig nødvendig etter at folk måtte forholde seg til mer enn ett språk. Den første norske ordboken var en juridisk fagordbok, Termini juridici, som utkom i København i 1634 (2). Etter hvert finnes det norske spesialordbøker innen mange fagområder, herunder flere medisinske ordbøker.

Den første norske medisinske ordbok ble utgitt i 1933 med Karl Evang (1902-81) som redaktør (3). Denne boken er senere redigert av Arnt Jakobsen (f. 1938), og 14. utgave ble utgitt i 2002 (4). I 1988 kom Audun Øyris (1926-2002) store og gode ordbok på nynorsk, som nå foreligger i 8 . utgave (5). Kunnskapsforlaget utga Medisinsk ordbok i 1990, først med Erik Kåss (1923-97), senere med Magne Nylenna (f. 1952) som redaktør. 7. utgave er nylig utgitt (6). En norsk utgave av Bengt I. Lindskogs (f. 1929) svenske Medicinsk terminologi ble utgitt av Universitetsforlaget i 1998, og er senere overtatt av Gyldendal Akademisk forlag (7). I 2006 utga Lunde forlag Medisinsk ordbok med Øystein Lappegard (f. 1952) som redaktør (8). Noen mindre lommeordbøker er også tilgjengelige, samt tospråklige medisinske ordbøker, bl.a. en norsk-samisk medisinsk lommeparlør ved Egil Utsi (f. 1949) (9) og ordbøker på norsk-engelsk/engelsk-norsk (10) og norsk-tysk/tysk-norsk (11). De medisinske ordbøkene som i dag er tilgjengelige på norsk, utgis av ulike forlag, har ulike målgrupper, ulik bakgrunn og ulike redaktører. Et forslag om å slå disse bøkene sammen for å lage «en eller to riktig gode» (3), blir omtrent som å foreslå at Tidsskriftet, Dagens Medisin og det som ellers måtte finnes av medisinske tidsskrifter her i landet, slås sammen med samme begrunnelse.

\section{Hva er en medisinsk ordbok?}

En ordbok skiller seg fra et leksikon (en ensyklopedi) ved at den kun inneholder språklig informasjon, mens et leksikon domineres av ikke-språklig, faktisk informasjon om det aktuelle begrepet eller fenomenet.

En god fagordbok har to hovedfunksjoner: å gi informasjon om selve oppslagsordet (ortografi etc.) og å gi en faglig forklaring knyttet til ordet (12).

Det er tre grunnleggende oppgaver i det å lage en medisinsk, og sikkert også enhver annen fagspesifikk, ordbok:

- Hvilke ord skal inkluderes?

- Hvordan skal ordene bokstaveres?

- Hvordan kan det lages en kort, klar og konsis definisjon av ordet?

\section{Ordvalg}

Mens en allmennordbok gjerne vil være heldekkende og inkludere alle ord som brukes i dagligtale, er ordvalget annerledes $i$ en fagordbok. En medisinsk ordbok vil ta utgangspunkt i ord og begreper som er fagspesifikke og som oftest nettopp ikke finnes $i$ en allmennordbok. Til gjengjeld vil en medisinsk ordbok ikke inkludere vanlige ord, dersom ikke disse ordene har en spesifikk betydning i faglig sammenheng (f.eks. signifikant, tegn, toleranse, valid).

All sakprosa, som ordbøkene er en spesiell undergruppe av, bør ha en mer eller mindre veldefinert målgruppe. Når det gjelder ordvalget for Kunnskapsforlagets medisinske ordbok (6), tar jeg utgangspunkt i de behov som jeg antar at en fersk sykepleiestudent vil ha.

Oppslagsordene kan deles i tre hovedgrupper:

- Medisinske basalfag (anatomi, fysiologi, immunologi, genetikk etc.)

- Klinisk medisin (diagnostikk og behandling av sykdommer)

- Helsevesenets oppbygning og funksjon (profesjoner, institusjoner, prosedyrer og organisatoriske fenomener)

Min egen erfaring er at det er innen den siste av disse tre gruppene at ord endres og foreldes raskest og oppdateringsbehovet er størst.

De færreste av dagens ordbøker blir til «fra bunnen av» ved hjelp av enkeltpersoners møysommelige innsamling av ord på Ivar Aasens (1813-96) vis. Valget av oppslagsord, lemmautvalget i leksikografisk terminologi, er mer et resultat av systematiske søk og bruk av definerte kilder. Tidligere, ev. også utenlandske, ordbøker er en vanlig kilde.

Som ordboksredaktør venner man seg til å samle potensielle «nyord» kontinuerlig. En viktig kilde i mitt eget ordboksarbeid er hvert nytt nummer av Tidsskriftet, som skummes med tanke på nye fagspesifikke ord som er viktige og tidløse nok til at målgruppen vil kunne lete etter dem. Tilsvarende vil gjennomgang av de alfabetiske registrene i nye lærebøker innen ulike medisinske fagfelter kunne gi fangst. Gode venners og kollegers forslag til nye ord er også viktige. Nytt er muligheten for å gjennomgå de lange listene av ord som forekommer i dikterte tekster i talegjenkjenningssystemer.

En klassisk problemstilling i alle oppslagsverker har vært balansen mellom antall oppslagsord innen ulike spesialiteter eller begrepsområder. Om halvparten av oppslagsordene i en medisinsk ordbok refererte seg til psykisk helse, ville det virke påfallende. I rene elektroniske ordbøker og leksika vil dette ikke være direkte synlig for brukerne. Likevel diskuteres problemet også i Wikipedia, der såkalte «inclusionists» ønsker flest mulig oppslagsord, mens såkalte «deletionists» ønsker et mer balansert innhold (13).

Forkortelser utgjør en spesiell ufordring. Å avgjøre når en forkortelse bør inkluderes, er vanskelig, men igjen hjelper det å tenke på sykepleiestudenten som prototype for brukerne. Med både et økende antall og en økende bruk av forkortelser i helsetjenesten 
er det naturlig at antall forkortelser også øker i en medisinsk ordbok. Eksempler på nye forkortelser i 7. utgave av Medisinsk ordbok (6) er EPJ (elektronisk pasientjournal), LAR (legemiddelassistert rehabilitering) og TBE (tick-born encephalitis). Selve oppslagsordene, som presenteres alfabetisk, er inngangen til den enkelte artikkel (som er betegnelsen på de få ordene eller linjene som følger etter). Oppslagsordene blir normalt oppført i grunnformen av ordet, dvs. ubestemt form entall av substantiver og infinitiv av verb (2).

\section{Stavemåte}

Et av hovedmålene med en norsk medisinsk ordbok er å støtte oppunder en norskspråklig medisinsk terminologi. Opptaket av utenlandske, spesielt engelskspråklige ord og uttrykk i det norske språket er stort og økende, ikke minst innen fagspråk som det medisinske. Anglonorsk viser seg bl.a. $i$ en tiltakende særskriving, dvs. en kunstig oppdeling av ord som skal samskrives på norsk (f.eks. polymerasekjedereaksjon, ikke polymerase kjede reaksjon). Et norsk medisinsk språk er viktig både fordi pasientene er norske og forventer (og fortjener) forståelige ord og uttrykk, og fordi vi har en nasjonal, kulturell forpliktelse til å tilpasse også det medisinske fagspråket til vår norske språktradisjon.

Et vanlig prinsipp er at når latinske og greske former av anatomiske betegnelser og diagnoser brukes, så skrives de oftest i sin klassiske form (thorax, asthma bronchiale), likedan i sammensatte ord (thoraxkirurgi), mens avledningsord fornorskes (torakal, astmatisk).

Stavemåten (ortografien) av fagtermer er den mest normative funksjonen til en medisinsk ordbok. Stavemåten i Medisinsk ordbok (6) brukes f.eks. i norske sykehus som standardform i talegjenkjenningssystemer levert av Max Manus AS. Som en motkraft til anglofiseringen av fagspråket i sin alminnelighet, får stadig flere termer en norsk skriveform. Samtidig er det viktig å erkjenne at språk i sin alminnelighet og fagspråk i særdeleshet er «markedsstyrt». Fornorskede skrivemåter av for eksempel c- og ch- er gjennomført der det anses mulig (f.eks. katarakt og kirrhose som nye skriveformer i siste utgave) og $\mathrm{x}$ er stort sett erstattet av ks. På den annen side er skriveformene cancer og thorax beholdt. Ord og uttrykk må gjenkjennes av dem som benytter dem i det daglige, og det er sjelden vellykket å presse på brukerne ord som oppfattes som kunstige, selv om de formelt sett er språklig korrekte. Derfor heter det fortsatt «donor» (om organgivere) selv om det kanskje burde hete «donator» (14). Slike vurderinger blir nødvendigvis skjønnsmessige, og ikke sjelden kontroversielle.

Anbefalte norske skriveformer gjør en ordbok nyttig også for brukere som ellers er godt fortrolige med den faglige betyd- ningen av de fleste ord og uttrykk. Man får dessuten råd om norske avløserord som er like presise som fremmedordene (f.eks. etterlevelse for compliance og nakkesleng for whiplash), og om at kronisk utmattelsessyndrom bør foretrekkes fremfor andre formuleringer av diagnosen.

\section{Ordforklaring}

Selve definisjonen av fagtermers betydning synes å være det minst kontroversielle ved en medisinsk ordbok. Å lage korte, presise, men likevel opplysende ordforklaringer er ikke alltid enkelt. For mer omfattende utredninger av et begrep må det vises til leksika eller lærebøker. Der det finnes autoritative definisjoner (f.eks. i lover eller forskrifter), benyttes disse. Definisjoner skal ikke inneholde ord som ikke finnes andre steder i ordboken, og de bør bygges opp hierarkisk slik at det først forklares hvilken begrepsgruppe ordet tilhører (legemiddel, sykdom, muskel e.l.), og deretter hva som er spesifikt nettopp for det aktuelle ordet.

Ofte innledes forklaringen med synonyme begreper. Typisk vil latinske og andre fremmedspråklige former av ordet følge etter den norske, og omvendt. Som en erkjennelse av brukernes begrensede etterspørsel inneholder de fleste medisinske ordbøker lite etymologi. Det er heller ikke vanlig at fagordbøker inneholder mye informasjon om grammatikalske forhold (12). Ved hjelp av krysshenvisninger settes begreper inn i en sammenheng (distal, motsatt: proksimal, abduksjon, motsatt: adduksjon). Selv erfarne leger vil finne nyttig informasjon om forskjellen mellom foreskrive og forskrive, og mellom symptom og tegn.

\section{Aldri komplett, aldri feilfri}

Arbeidet med en ordbok er ikke nøytralt og objektivt. Redaktørens egen fagbakgrunn og språkoppfatning har ganske sikkert betydning for både ordvalg, skrivemåter og ordforklaringer. Alle eksisterende norske medisinske ordbøker har vært og er redigert av medisinere med ulik spesialisering. I tillegg til interesse for medisinsk språk trengs systematikk, nøyaktighet og tålmodighet. Arbeidet er tidkrevende, og i motsetning til store allmenne ordboksprosjekter med mange heltidsansatte er det som regel en «enmannsaktivitet». Det utføres for de fleste på kvelder, i helger og ferier og med amatørers (i leksikografisk forstand) entusiasme.

Leksikografers og filologers sannsynligvis velbegrunnede kritikk av manglende språklig konsekvens oppveies forhåpentligvis av nærheten til faget og ordenes innhold. Ordbøker er bruksbøker i ordets rette forstand. At brukerne finner de ordene de leter etter, og at ordforklaringene er opplysende, er de viktigste suksesskriteriene. I tillegg kommer nytten av de anbefalte skrivemåter av ord og uttrykk.
Utgivelsen av én ordboksutgave er begynnelsen på arbeidet med den neste. Elektroniske versjoner gjør det nå mulig å foreta suppleringer og rettelser også mellom de ordinære utgavene. En ordbok blir aldri komplett, og forbedringer er avhengig av hjelp fra kritiske lesere og brukere.

\section{Magne Nylenna}

magne.nylenna@helsebiblioteket.no Helsebiblioteket

Nasjonalt kunnskapssenter for helsetjenesten Postboks 7004 St. Olavs plass

0130 Oslo

Oppgitte interessekonflikter: Forfatteren er redaktør av Medisinsk ordbok som utgis av Kunnskapsforlaget

Litteratur

1. Wikiquote. http://en.wikiquote.org/wiki/ Wittgenstein\#Tractatus_Logico-Philosophicus 281922.29 (30.9.2009).

2. Fjeld RV, Vikør LS. Ord og ordbøker. Kristiansand: Høyskoleforlaget, 2008

3. Hem E. Medisinsk ordbok i ny utgave. Anmeldelse av: Nylenna M, red. Medisinsk ordbok. 6. utg Tidsskr Nor Lægeforen 2004; 124: 2650.

4. Jakobsen A. Norsk medisinsk ordbok. 14. utg. Oslo: Sem og Stenersen, 2002.

5. Øyri A, Øyri B. Norsk medisinsk ordbok. 8. utg. Oslo: Samlaget, 2007

6. Nylenna M. Medisinsk ordbok. 7. utg. Oslo: Kunnskapsforlaget, 2009.

7. Lindskog BI. Gyldendals store medisinske ordbok 2. utg. Oslo: Gyldendal Akademisk, 2003.

8. Lappegard $\emptyset$. Medisinsk ordbok. Oslo: Lunde, 2006

9. Utsi E. Medisinsk lommeparlør norsk-samisk. Karasjok: Davvi Girji, 1998

10. Engelsk medisinsk ordbok: engelsk-norsk/norskengelsk. Oslo: Kunnskapsforlaget, 2009.

11. Porthun EH. Medisinsk lommeordbok: norsk-tysk tysk-norsk. Bøverbru: Ondefo, 2006.

12. Bergenholtz H, Tarp S. Manual i fagleksikografi. Herning: Forlaget systime, 1994

13. The battle for Wikipedia's soul. The Economist 6.3.2008. www.economist.com/sciencetechnology/ $\mathrm{tq} /$ displayStory.cfm?story_id=E1_TDSRJPVQ (18.9.2009).

14. Flo $\AA$ ødegaard R. Legelatin i nordisk perspektiv. Tidsskr Nor Lægeforen 2000; 120: 2053.

Manuskriptet ble mottatt 17.8. 2009 og godkjent 5.10. 2009. Medisinsk redaktør Raida Ødegaard. 